\title{
Assessment of the electrocardiogram in dogs with visceral leishmaniasis ${ }^{1}$
}

\author{
Marlos G. Sousa ${ }^{2 *}$, Roberta Carareto $^{2}$, Jeanna G. Silva² and Juliana Oliveira ${ }^{2}$
}

\begin{abstract}
Sousa M.G., Carareto R., Silva J.G. \& Oliveira J. 2013. Assessment of the electrocardiogram in dogs with visceral leishmaniasis. Pesquisa Veterinária Brasileira 33(5):643647. Escola de Medicina Veterinária e Zootecnia, Universidade Federal do Tocantins, Rodov. BR-153 Km 112, Araguaína, T0, 77800-970, Brazil, E-mail: marlos@uft.edu.br

As myocarditis and arrhythmias have been shown to occur in both human beings and dogs with leishmaniasis, electrocardiograms of 105 dogs serologically positive for this disease were assessed for rhythm disturbances and changes in ECG waves. A few expressive alterations were seen, including sinus arrest, right bundle branch block, and atrial premature beats in $14.3 \%, 4.8 \%$, and $4.8 \%$ of the studied subjects, respectively. Also, the analysis of ECG waves showed changes suggestive of left atrium and ventricle enlargements, and myocardial hypoxia in some animals. Although cardiac compromise has been previously reported in dogs with leishmaniasis, only a small subset of dogs showed any alteration in the electrocardiogram, which cannot support the occurrence of myocarditis in this investigation.
\end{abstract}

INDEX TERMS: Visceral leishmaniasis, electrocardiography, arrhythmias, canines, protozoan, electrophysiology.

RESUMO.- [Avaliação do eletrocardiograma em cães com leishmaniose visceral.] Devido à identificação prévia de miocardite e arritmias tanto em seres humanos quanto em cães portadores de leishmaniose, 105 cães com sorologia positiva para tal enfermidade tiveram seus eletrocardiogramas avaliados quanto à presença de distúrbios do ritmo e alterações nas ondas eletrocardiográficas. Poucas variações expressivas foram observadas, exceto parada sinusal, bloqueio de ramo direito e complexos atriais prematuros em $14,3 \%, 4,8 \%$, e $4,8 \%$ dos pacientes estudados, respectivamente. Ademais, a análise do ECG demonstrou alterações sugestivas de sobrecarga do átrio e do ventrículo esquerdos e hipóxia do miocárdio. Embora o comprometimento cardíaco em cães com leishmaniose já tenha sido demonstrado anteriormente, apenas uma pequena parte dos cães avaliados apresentou alteração no eletrocardiograma, não sendo possível correlacionar com a ocorrência de miocardite nesta pesquisa.

TERMOS DE INDEXAÇÃO: Leishmaniose visceral, eletrocardiografia, arritmias, caninos, protozoário, eletrofisiologia.

\footnotetext{
${ }^{1}$ Received on October 2, 2012.

Accepted for publication on March 18, 2013.

${ }^{2}$ Escola de Medicina Veterinária e Zootecnia, Universidade Federal do Tocantins (UFT), Rodov. BR-153 Km 112, Campus EMVZ/UFT, Araguaína, T0 77800-970, Brazil. *Corresponding author: marlos@uft.edu.br
}

\section{INTRODUCTION}

Visceral leishmaniasis is a generalized infection of the mononuclear phagocyte system, caused by the protozoan Leishmania chagasi. It is known to have a high viscerotropism and its transmission results from bites of phlebotomine sand flies containing the infective promastigote form. Although different modalities of the disease have been documented, the infection is presented clinically by irregular fever, anemia, hepatosplenomegaly, intestinal disorders, hemorrhages, weight loss, alopecia or hypotrichosis, and several other associated signs (Cimerman \& Cimerman 2001).

Because of the multisystemic nature of leishmaniasis, the parasite may infect several corporal tissues in human beings, dogs, and many other animals. One of the most important features of visceral leishmaniasis in humans remains on the compromise of organs related to the mononuclear phagocyte system where the parasite multiplies, leading to the organ enlargement in response to infection (Cimerman \& Cimerman 2003).

Although relatively uncommon, this protozoan may lead to the development of myocarditis, which has been reported in both dogs (Büngener \& Mehlitz, 1977, Font et al. 1993, Torrent et al. 2005) and human beings, and was characterized by histological alterations that, when seve- 
re enough, present edema, leukocyte infiltration, focal necrosis, and proliferation of Anitschkow myocytes. All these alterations were once named as "reactional myocardium" (De-Morais et al. 1988, Puerto-Alonso et al. 2006). In acute form, myocarditis generally results in an unexplained development of arrhythmias or cardiac failure after a recent episode of infectious disease. Its diagnosis may be equivocal because of the absence of clinical or clincopathological findings specific for myocarditis (Kittleson \& Kienle 1998).

When myocarditis is present, several unspecific changes on the electrocardiogram (ECG) are generally documented, including, but not limited to, changes in the ST-segment, in the amplitude of $\mathrm{T}$ wave and QRS complex and the occurrence of atrioventricular conduction disturbances. Besides that, signs of hypokinesia of the myocardial walls, altered myocardium echogenicity, or pericardial effusion can be detected in the echocardiographic examination (De-Morais et al. 1988, Kittleson \& Kienle 1998, Torrent et al. 2005).

Because of the increasing number of dogs with leishmaniasis and prolonged pauses and/or evidence of arrhythmias on auscultation, this study was aimed to assess cardiac rhythm and the ECG parameters in dogs with confirmed visceral leishmaniasis.

\section{MATERIALS AND METHODS}

One-hundred-five mature dogs of either sex ( 55 males and 50 females), with mean weight of $9.8 \mathrm{~kg}$ (2.6 to $31.3 \mathrm{~kg}$ ), serologically positive for visceral leishmaniasis by indirect immunofluorescence and Elisa with title higher than 1:40, were prospectively included in the study. All animals presented at least three of the following clinical signs suggestive of leishmaniasis: hypotrichosis, periocular alopecia, weight loss, onycogriphosis, skin lesions, and either hyporexia or anorexia, besides lymphadenomegaly and/or hepatosplenomegaly detected at physical examination.

Standard 6-lead computer-based ECGs (leads I, II, III, aVR, aVL, aVF) were recorded for three minutes in all dogs positioned in right lateral recumbency with a speed of $50 \mathrm{~mm} / \mathrm{s}$, calibrated for 10 $\mathrm{mm} / \mathrm{mV}$. Electrocardiograms were evaluated for cardiac rhythm, $\mathrm{P}$ wave duration $\left(\mathrm{P}_{\mathrm{ms}}\right)$ and amplitude $\left(\mathrm{P}_{\mathrm{mV}}\right), \mathrm{PR}$ and QT intervals duration, QRS complex duration, $\mathrm{R}$ wave amplitude, and heart rate (HR). Also, ST segment was assessed regarding its level, as well as the $\mathrm{T}$ wave regarding its polarity $\left(\mathrm{T}_{\mathrm{pol}}\right)$ and amplitude $\left(\mathrm{T}_{\mathrm{mV}}\right)$. Lead II was chosen to assess such parameters, whereas the mean electrical axis (MEA) was calculated through the net QRS amplitude of leads I and III.The duration of both P wave and QRS complex was compared with the normal range proposed by Wolf et al. (2000), while the comparison of the remaining parameters was accomplished against the reference table of Tilley \& Burtnick (2004).

Mean and standard deviations were calculated for the parametric data, while the non-parametric results were grouped by percentage of occurrence. Chi-square test was applied to contingency tables created to check for differences in the occurrence of arrhythmias according to gender (males vs. females) and body weight (up to $5 \mathrm{~kg}$, from 5.1 to $15 \mathrm{~kg}$, and greater than $15.1 \mathrm{~kg}$ ). An unpaired T test was calculated to investigate differences in the parametric results between males and females, as well as an one-way analysis of variance for the several variables according to body weight. The software Prism for Windows (Prism v.5.04, Graphpad Software, San Diego, CA, USA $)^{3}$ was used for all analyses, and significance was set at $\mathrm{P}<0.05$.

\footnotetext{
${ }^{3}$ Prism v.5.04, Graphpad Software, San Diego, CA, USA.
}

\section{RESULTS}

Several breeds were represented in the study, including Pinscher (6.7\%), English Cocker Spaniel (2.8\%), Boxer and German Shepherd (1.9\% each), Dalmation, Lhasa-Apso, and Rottweiller $(0.9 \%$ each), but the majority of the dogs were mixed-breed animals (82.9\%). Regarding gender and body weight, $52.4 \%$ were male and $47.6 \%$ were female, whereas $38.1 \%$ weighed less than $5 \mathrm{~kg}, 47.6 \%$ weighed between 5.1 and $15 \mathrm{~kg}$, and the minority (14.3\%) weighed over $15.1 \mathrm{~kg}$. The distribution of rhythms and conduction disturbances in dogs with confirmed visceral leishmaniasis is represented on Table 1. Some important findings are shown in Figure 1 . For the purpose of creating a contingency table to allow chi-square analyses to be performed, only abnormal rhythms were considered as arrhythmias, which included atrial premature beats, bundle branch blocks, and sinus arrest. The remainder of rhythms documented in this investigation was considered as non-arrhythmia. Therefore, statistical significance was not attained by chi-square for the occurrence of arrhythmias according to gender (Figure 2, $P=0.3822$ ). Sinus arrhythmia with wandering pacemaker was more prevalent in males, and females more frequently presented sinus arrhythmia. However, differences regar-

Table 1. Percent distribution of cardiac rhythms and conduction disturbances identified in dogs with confirmed visceral leishmaniasis

$$
\text { Cardiac rhythm }(\mathrm{n}=105)
$$

28.6\% Sinus arrhythmia with wandering pacemaker

$23.7 \%$ Sinus arrhythmia

$14.3 \%$ Sinus rhythm

9.5\% Sinus arrhythmia with wandering pacemaker and sinus arrest

$9.5 \%$ Sinus tachycardia

4.8\% Sinus arrhythmia with wandering pacemaker and right bundle branch block

$4.8 \%$ Sinus arrhythmia with atrial premature beats

4.8\% Sinus arrhythmia with sinus arrest

\begin{tabular}{|c|c|c|c|}
\hline \multicolumn{2}{|l|}{ Cardiac rhythm } & $\begin{array}{c}\text { Males } \\
(n=55)\end{array}$ & $\begin{array}{c}\text { Females } \\
(n=50)\end{array}$ \\
\hline \multicolumn{2}{|l|}{ Sinus arrhythmia } & $18.2 \%$ & $30.0 \%$ \\
\hline \multicolumn{2}{|l|}{ Sinus arrhythmia with atrial premature beats } & - & $10.0 \%$ \\
\hline \multicolumn{2}{|l|}{ Sinus arrhythmia with wandering pacemaker } & $36.3 \%$ & $20.0 \%$ \\
\hline \multicolumn{2}{|c|}{$\begin{array}{l}\text { Sinus arrhythmia with wandering pacemaker and } \\
\text { right bundle branch block }\end{array}$} & $9.1 \%$ & - \\
\hline \multicolumn{2}{|c|}{$\begin{array}{l}\text { Sinus arrhythmia with wandering pacemaker and } \\
\text { sinus arrest }\end{array}$} & $9.1 \%$ & $10.0 \%$ \\
\hline \multicolumn{2}{|l|}{ Sinus arrhythmia with sinus arrest } & $9.1 \%$ & - \\
\hline \multicolumn{2}{|l|}{ Sinus rhythm } & $9.1 \%$ & $20.0 \%$ \\
\hline \multicolumn{2}{|l|}{ Sinus tachycardia } & $9.1 \%$ & $10.0 \%$ \\
\hline Cardiac rhythm & $\begin{array}{l}\leq 5 \mathrm{~kg} \\
\mathrm{n}=40)\end{array}$ & $\begin{array}{l}5.1 \text { to } 15 \mathrm{~kg} \\
(\mathrm{n}=50)\end{array}$ & $\begin{array}{l}\geq 15.1 \mathrm{~kg} \\
(\mathrm{n}=15)\end{array}$ \\
\hline Sinus arrhythmia & $\%$ & $40.0 \%$ & - \\
\hline $\begin{array}{l}\text { Sinus arrhythmia with atrial premature } \\
\text { beats }\end{array}$ & $12.5 \%$ & - & - \\
\hline $\begin{array}{l}\text { Sinus arrhythmia with wandering pace- } \\
\text { maker }\end{array}$ & $25.0 \%$ & $20.0 \%$ & $66.7 \%$ \\
\hline $\begin{array}{l}\text { Sinus arrhythmia with wandering pace- } \\
\text { maker and right bundle branch block }\end{array}$ & $12.5 \%$ & - & - \\
\hline $\begin{array}{l}\text { Sinus arrhythmia with wandering pace- } \\
\text { maker and sinus arrest }\end{array}$ & $25.0 \%$ & - & - \\
\hline Sinus arrhythmia with sinus arrest & - & $10.0 \%$ & - \\
\hline Sinus rhythm & - & $20.0 \%$ & $33.3 \%$ \\
\hline Sinus tachycardia & $12.5 \%$ & $10.0 \%$ & - \\
\hline
\end{tabular}




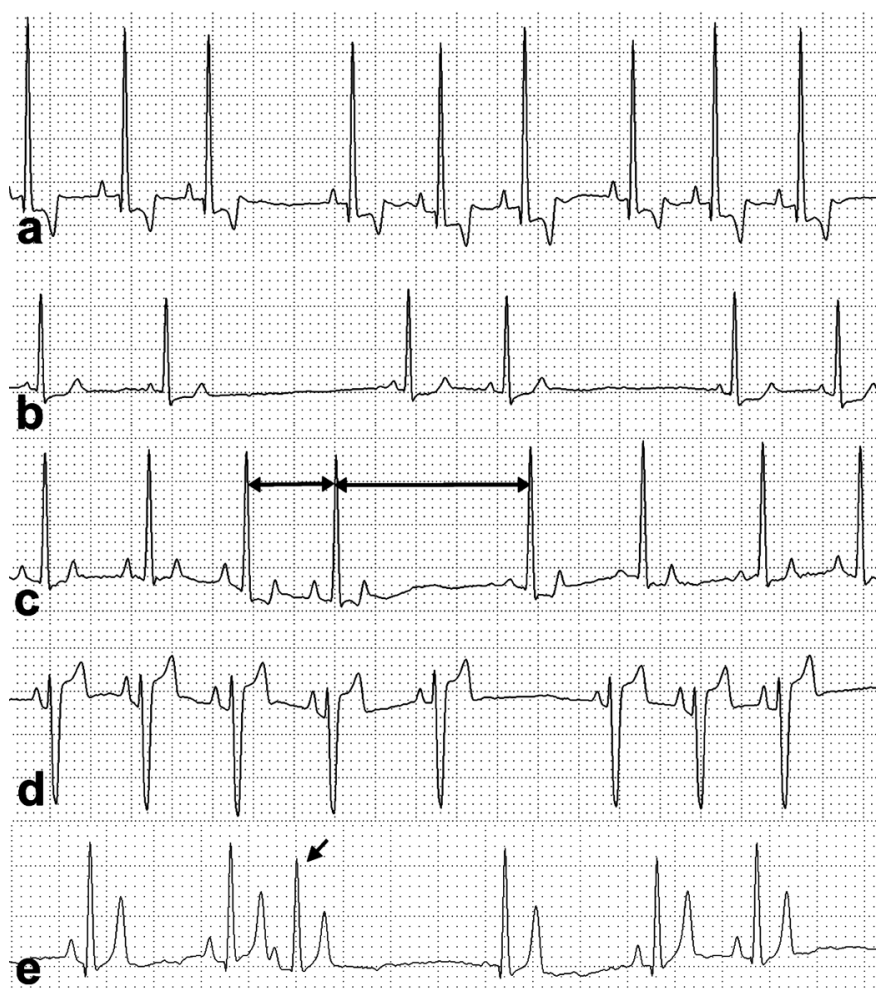

Fig.1. Representative ECG findings in dogs with visceral leishmaniasis. (a) Sinus arrhythmia; (b) and (c) sinus arrest. The first marked RR interval has $440 \mathrm{msec}$, with the next one being more than two-fold longer at $947 \mathrm{msec}$. Wandering pacemaker is also present - notice the varying amplitude of $\mathrm{P}$ waves; (d) incomplete right bundle branch block; (e) atrial premature beat (arrow). Also seen are the spiked T waves (All ECG tracings are shown in lead II, $50 \mathrm{~mm} / \mathrm{s}, 1 \mathrm{~cm}=1 \mathrm{mV}$ ).

ding cardiac rhythms were found when taking body weight into account, with chi-square test demonstrating statistical significance (Figure $3, \mathrm{P}<0.0001$ ) in this setting. Arrhythmias and conduction disturbances were significantly more frequent in dogs weighting less than $5 \mathrm{~kg}$.

Increased $\mathrm{P}_{\mathrm{ms}}$ was documented in $33.3 \%$ of the dogs, whereas $26.7 \%$ showed increased duration of the QRS complex. Also, spiked T waves and ST segment shifts were demonstrated in approximately $19.0 \%$ and $9.5 \%$,of the studied animals, respectively. Mean and standard deviations of the numeric parameters are listed on Table 2. The comparison of these parameters considering gender showed a significant difference $(P=0.0497)$ for $Q T$ interval only.

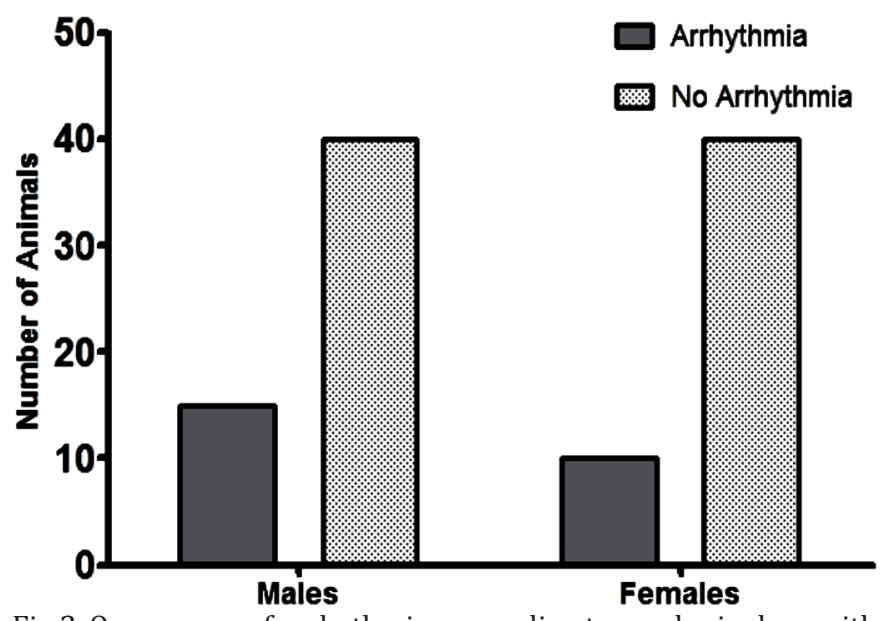

Fig.2. Occurrence of arrhythmias according to gender in dogs with visceral leishmaniasis. Chi-square test $(\mathrm{P}=0.3822)$ attained no statistical significance when only atrial premature beats, bundle branch blocks, and sinus arrest were considered as arrhythmias or conduction disturbances.

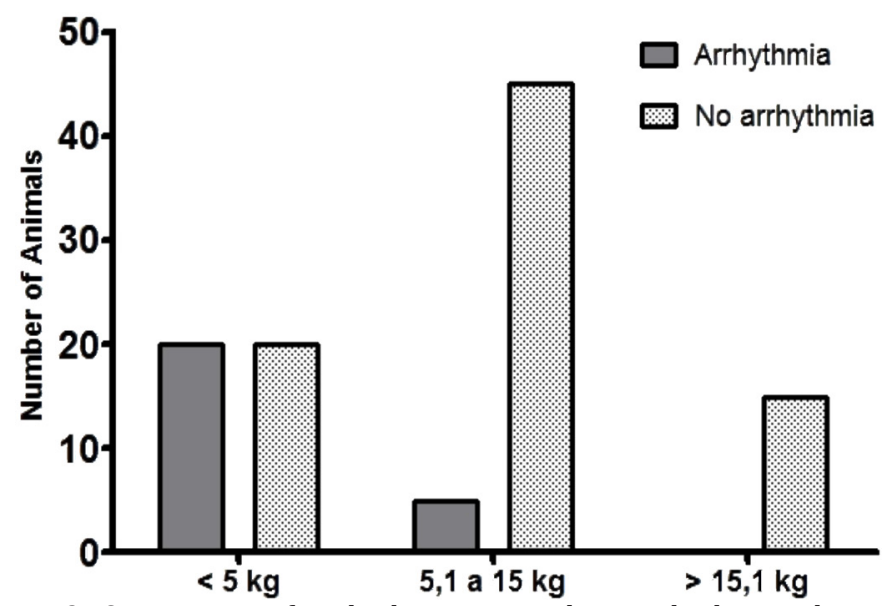

Fig.3. Occurrence of arrhythmias according to body weight in dogs with visceral leishmaniasis. Statistical significance was recorded for chi-square test $(\mathrm{P}<0.0001)$ when comparing the occurrence of atrial premature beats, bundle branch blocks, and sinus arrest grouped as arrhythmias or conductions disturbances versus the remainder of cardiac rhythms.

When body weight was considered, comparison was also significantly different $(\mathrm{P}=0.0259)$ for $\mathrm{R}$ wave amplitude. The distribution of the non-parametric data is shown on Table 3.

Table 2. Mean and standard deviation of the ECG parametric parameters recorded in dogs with confirmed visceral leishmaniasis

\begin{tabular}{ccccccc}
\hline Parameter $^{\mathrm{a}}$ & All dogs $(\mathrm{n}=105)$ & Males $(\mathrm{n}=55)$ & Females $(\mathrm{n}=50)$ & $\leq 5 \mathrm{Kg}(\mathrm{n}=40)$ & 5.1 to $15 \mathrm{Kg}(\mathrm{n}=50)$ & $\geq 15.1 \mathrm{~kg}(\mathrm{n}=15)$ \\
\hline $\mathrm{P}_{\mathrm{ms}}$ & $46.9 \pm 5.1$ & $46.9 \pm 6.1$ & $46.9 \pm 4.0$ & $49.1 \pm 3.4$ & $44.2 \pm 5.5$ & $50.0 \pm 3.0$ \\
$\mathrm{P}_{\mathrm{mV}}$ & $0.20 \pm 0.06$ & $0.18 \pm 0.05$ & $0.22 \pm 0.06$ & $0.21 \pm 0.08$ & $0.20 \pm 0.04$ & $0.20 \pm 0.07$ \\
$\mathrm{PR}$ & $87.7 \pm 12.8$ & $89.7 \pm 15.6$ & $85.8 \pm 9.3$ & $85.9 \pm 14.4$ & $86.8 \pm 11.4$ & $96.7 \pm 14.2$ \\
QRS & $58.6 \pm 10.7$ & $60.3 \pm 14.4$ & $56.8 \pm 4.1$ & $59.2 \pm 17.0$ & $56.7 \pm 3.6$ & $63.3 \pm 3.5$ \\
$\mathrm{R}$ & $1.02 \pm 0.46$ & $1.13 \pm 0.37$ & $0.90 \pm 0.53$ & $0.70 \pm 0.30^{\mathrm{C}}$ & $1.19 \pm 0.47^{\mathrm{D}}$ & $1.32 \pm 0.26^{\mathrm{D}}$ \\
$\mathrm{QT}$ & $198.8 \pm 21.9$ & $207.6 \pm 25.7^{\mathrm{A}}$ & $189.0 \pm 11.7^{\mathrm{B}}$ & $195.9 \pm 22.2$ & $198.0 \pm 21.1$ & $209.0 \pm 30.0$ \\
HR & $111.7 \pm 30.6$ & $101.9 \pm 28.3$ & $122.4 \pm 30.7$ & $114.9 \pm 39.3$ & $113.7 \pm 26.0$ & $96.3 \pm 22.4$
\end{tabular}

${ }^{\text {a }} \mathrm{P}_{\mathrm{ms}}$ : duration of $\mathrm{P}$ wave (msec); $\mathrm{P}_{\mathrm{mV}}=$ amplitude of $\mathrm{P}$ wave $(\mathrm{mV}) ; \mathrm{PR}=$ duration of $\mathrm{PR}$ interval (msec); $\mathrm{QRS}=$ duration of $\mathrm{QRS}$ complex (msec); R = amplitude of R wave (mV); QT = duration of QT interval (msec); HR = heart rate (bpm). ${ }^{\mathrm{A}, \mathrm{B}}$ Significant difference in QT interval males and females. ${ }^{\mathrm{C} D}$ Significant difference in $\mathrm{R}$ wave amplitude according to body weight. 
Table 3. Percent distribution of the ECG non-parametric data recorded in dogs with confirmed leishmaniasis

\begin{tabular}{|c|c|}
\hline Parameter $^{\mathrm{a}}$ & All dogs $(n=105)$ \\
\hline ST & $4.8 \%$ ST elevation; $4.8 \%$ ST depression \\
\hline $\mathrm{T}_{\mathrm{pol}}$ & $57.1 \%$ positive $\mathrm{T} ; 38.1 \%$ biphasic $\mathrm{T} ; 4.8 \%$ negative $\mathrm{T}$ \\
\hline $\mathrm{T}_{\mathrm{mV}}^{\mathrm{pol}}$ & $\begin{array}{l}19.0 \% \mathrm{~T} \text { wave amplitude greater than } 25 \% \text { of } \mathrm{R} \text { wave ampli- } \\
\text { tude }\end{array}$ \\
\hline MEA & $61.9 \% 60-80$ degrees; $23.8 \% 80-100$ degrees; $9.5 \%$ lower than \\
\hline & 40 degrees; $4.8 \%$ 40-60 degrees \\
\hline
\end{tabular}

a $\mathrm{ST}$ = ST segment; $\mathrm{T}_{\mathrm{pol}}=$ polarity of $\mathrm{T}$ wave; $\mathrm{T}_{\mathrm{mV}}$ amplitude of $\mathrm{T}$ wave; MEA $=$ mean electrical axis.

\section{DISCUSSION}

The majority of the dogs enrolled in this study presented sinus arrhythmia with wandering pacemaker, which is considered a normal cardiac rhythm for canines (Tilley \& Burtnick 2004). However, an expressive amount of dogs were shown to have sinus arrest, which may explain the pauses frequently auscultated in these animals (Ohara 2007), but is uncommonly associated with myocarditis (Woolley et al. 2007). Paroxysmal sinus arrest may be a normal finding in brachycephalic dogs, attributable to the increase in vagal tone that accompanies inspiration, leading to an exaggerated sinus arrhythmia. Other causes of sinus arrest might be cervical neoplasms irritating the vagus nerve, pathologic conditions of the atria, as well as drug toxicities and electrolyte imbalance (Tilley \& Burtnick 2004). Although hemodynamically insignificant (Andrea et al. 2002), right bundle branch blocks were detected in some dogs. On the contrary, atrial premature beats were recorded in a few subjects and hemodynamic compromise may be attributable to such arrhythmia, especially when it occurs in sequence leading to atrial tachycardia (Kittleson \& Kienle 1998, Tilley \& Burtnick 2004, Artese 2007). In a study evaluating the cardiac injury owing to visceral leishmaniasis in people up to 19 years old, Diamantino (2010) found premature beats to occur in $44.9 \%$ of the studied subjects. However, that investigation used a holter recording to assess cardiac rhythm over a longer period of time, and also documented ventricular premature beats, which were not found in the animals of this study.

The difference documented in QT interval between males and females is likely attributable to heart rate, and, despite not statistically significant, was lower in males than females. This parameter is inversely related to QT interval (Kittleson \& Kienle 1998) and represents the total electrical activity of the ventricles, computing the time from the beginning of ventricular depolarization to its final repolarization (Tilley \& Burtnick 2004). Therefore, apart from heart rate, it might be influenced by factors that interfere with ventricular electrical activity, including electrolyte imbalance, which is not an uncommon finding in dogs with visceral leishmaniasis. Because no ventricular arrhythmias or conduction disturbances have been recorded in this investigation, it is unlikely that any abnormality actually existed within the ventricles of these animals. Nonetheless, the absence of a more detailed analysis of cardiac rhythm, including a holter evaluation over 24 hours, does not allow excluding paroxysmal ventricular arrhythmias. Also, the dogs did not undergo an echocardiogram to exclu- de any other cardiac condition known to cause ventricular arrhythmias. Concerning the difference documented in $\mathrm{R}$ wave amplitude among animals with varying body weight, it is supposedly ascribed to the amount of ventricular mass, which is greater in larger animals, therefore augmenting $R$ waves as the body weight increases (Artese 2007), as observed in the present study.

One of the main problems with visceral leishmaniasis relies on its long incubation period before the appearance of clinical disease in dogs, which can last from three months to seven years, resulting in many infected dogs being asymptomatic carriers that do not exhibit disease (Miró et al. 2008). Nevertheless, the parasite may cause inflammation of the heart and vessels, resulting in myocarditis (Torrent et al. 2005). Interestingly, a recent investigation demonstrated that in spite of the minimum-to-moderate inflammatory reaction characterized by mononuclear, perivascular, and intermuscular infiltrates being observed in both symptomatic and asymptomatic dogs on histopathological analysis of the heart, clinical examination of these animals have not disclosed any manifestations ascribed to cardiac compromise (Alves et al. 2010), in agreement with the animals of this study, which also showed no clinical signs that could be related to cardiac injury.

In fact, there are not many reports on literature regarding myocardial inflammation caused by Leishmania spp. in dogs (Büngener \& Mehlitz 1977, Torrent et al. 2005, López-Peña et al. 2009). Myocarditis itself may be caused by several other conditions, including toxins, direct invasion of myocardial tissue, and immune-mediated damage, resulting in focal or diffuse involvement of the cardiac tissue. Its clinical manifestations depend on the extent of the lesions, but generally are characterized by varying rhythm disturbances (Kittleson \& Kienle 1998), including malignant arrhythmias causing sudden death (Woolley et al. 2007). As shown previously, this investigation only recorded minor rhythm disturbances, although the electrocardiograms disclosed changes suggestive of left atrium and ventricle enlargements and hypoxia, as determined by enlarged $\mathrm{P}$ waves and QRS complexes, and spiked T waves, according to comparisons with the normal standards for similarly-sized dogs (Wolf et al. 2000, Tilley \& Burtnick 2004, Artese 2007). In a recent report from Spain, the ECG of a dog found on necropsy to have severe cardiac compromise due to leishmaniasis just showed low-amplitude QRS complexes with normal cardiac rhythm (López-Peña et al. 2009).

Our ECG findings, however, are not necessarily related to pathological processes within the myocardium, especially when one considers the lack of sensibility and specificity of the electrocardiogram to detect chamber enlargement based on the temporal and potential assessment of its waves (Kittleson \& Kienle 1998, Andrea et al. 2002). Nonetheless, it should be stressed that the left axis shift documented in some dogs may be ascribed to left heart enlargement itself (Tilley \& Burtnick 2004), which obviously needed echocardiographic confirmation.

Although the histopathological evaluation of the hearts could be rewarding in the animals where ECG abnormalities were recorded, it was not the purpose of this inves- 
tigation. Other studies in dogs with this disease have demonstrated a myocardium with a dense accumulation of macrophages between the muscle fibers, as well as areas of cardiac muscle atrophy, degeneration and loss of cardiomyocytes (Torrent et al. 2005, López-Peña et al. 2009). Also, Wooley et al. (2010) reported a case of a fainting dog, whose holter analysis documented episodes of no discernable electrical cardiac activity. The post-mortem examination of the heart showed evidence of myocarditis, with increased inflammatory cells and fibrous tissue throughout the atrial myocardium. Although a cause could not be demonstrated in that case, the sinus arrest was ascribed by the authors to chronic myocarditis and myocardial hemorrhage within the atria, with fibrosis adjacent to the sinoatrial node.

The main limitation of this study relies on the absence of a histopathological analysis of the hearts, particularly in those animals where conduction disturbances were identified on ECG tracings. Also, echocardiographic and cardiac biomarker analysis could bring additional information for the characterization of abnormalities within the heart of animals with this disease. Even though alterations in cardiac rhythm have not been detected in the majority of the dogs, some of the findings, such as atrial premature beats, might be attributable to a pathological process within the atrial myocardium. Nevertheless, no other changes compatible with this possibility were further detected.

Although cardiac compromise has been previously reported in dogs with leishmaniasis, only a small subset of dogs included in this study presented minor ECG alterations, with the most important being atrial premature beats. Sensitivity and specificity of the electrocardiogram in detecting cardiac abnormalities cannot be calculated because a gold standard method, such as histopathological analysis, was not performed. Our results can neither support nor rule out the occurrence of myocarditis in dogs with visceral leishmaniasis, since paroxysmal arrhythmias could exist and ECG tracings have been recorded for just a few minutes in each animal.

\section{REFERENCES}

Alves G.B.B., Pinho F.A., Silva S.M.M.S., Cruz M.S.P. \& Costa F.A.L. 2010. Cardiac and pulmonary alterations in symptomatic and asymptomatic dogs infected naturally with Leishmania (Leishmania) chagasi. Braz. J. Med. Biol. Res. 43:310-315.
Andrea E.M., Atié J. \& Maciel W. 2002. Eletrocardiograma na criança e no feto. In: Goldwasser G.P. (Ed.), Eletrocardiograma orientado para o clínico. $2^{\text {a }}$ ed. Revinter, Rio de Janeiro.

Artese J.M. 2007. Principios de electrocardiografía veterinária, p.105-120. In: Belerenian G., Mucha C.J., Camacho A.A. \& Grau J.M. (Eds), Afecciones cardiovasculares en pequeños animales. $2^{\underline{a}}$ ed. Inter-Médica, Buenos Aires.

Büngener W. \& Mehlitz D. 1977. Atypisch verlaufende Leishmania donovani infektion bei hunden. Tropenmed. Parasitol. 28:175-180.

Cimerman B. \& Cimerman S. 2001. Parasitologia humana e seus fundamentos gerais. $2^{\mathrm{a}}$ ed. Atheneu, São Paulo, 375p.

Cimerman S. \& Cimerman B. 2003. Medicina Tropical. Atheneu, Rio de Janeiro. 690p.

De-Morais C.F., Duarte M.I., Corbett C.E. \& Reis M.M. 1988 Morphologic cardiac changes in human visceral leishmaniasis: study based on 16 necropsy cases. Arq. Bras. Cardiol. 51:441-445.

Diamantino T.C.C. 2010. Leishmaniose visceral: avaliação das repercussões cardiovasculares secundárias à doença e ao tratamento em crianças e adolescentes tratadas com três esquemas terapêuticos. Tese de Doutorado, Universidade Federal de Minas Gerais, Belo Horizonte, MG. 221p.

Font A., Durall N., Domingo M., Closa J.M., Mascort J. \& Ferrer L. 1993. Cardiac tamponade in a dog with visceral leishmaniasis. J. Am. Anim. Hosp. Assoc. 29:95-100.

Kittleson M.D. \& Kienle R.D. 1998. Small Animal Cardiovascular Medicine. Mosby, St Louis. 603p.

López-Peña M., Alemañ N., Muñoz F., Fondevila D., Suárez M.L., Goicoa A. \& Nieto J.M. 2009. Visceral leishmaniasis with cardiac involvement in a dog: a case report. Acta Vet. Scand. 51:20-22.

Miró G., Cardoso L., Pennisi M.G., Oliva G. \& Baneth G. 2008. Canine leishmaniosis: new concepts and insights on an expanding zoonosis. Part two. Trends Parasitol. 24:371-377.

Ohara V.Y.T. 2007. Aproximación al paciente cardiópata, p.55-62. In: Belerenian G., Mucha C.J., Camacho A.A. \& Grau J.M. (Eds), Afecciones cardiovasculares en pequeños animales. $2^{\mathrm{a}}$ ed. Inter-Médica, Buenos Aires.

Puerto-Alonso J.L., Molina-Ruano F.J., Gómez-Soto F. \& Gómez-Rodríguez F. 2006. Visceral leishmaniasis with cardiac affectation in an immunocompetent patient. Med. Clin. (Barc.) 127:519.

Tilley L.P. \& Burtnick N.L. 2004. ECG Eletrocardiografia para o clínico de pequenos animais. Roca, São Paulo. 99p.

Torrent E., Leiva M., Segalés J., Franch J., Peña T., Cabrera B. \& Pastor J. 2005. Myocarditis and generalised vasculitis associated with leishmaniosis in a dog. J. Small Anim. Pract. 46:549-552.

Wolf R., Camacho A.A. \& Souza R.C.A. 2000. Eletrocardiografia computadorizada em cães. Arq. Bras. Med. Vet. Zootec. 52:610-615.

Woolley R., Blundell R., Else R., Corcoran B., Devine C. \& French A. 2007. Atrial myocarditis as a cause of sinus arrest in a dog. J. Small Anim. Pract. 48:455-457. 